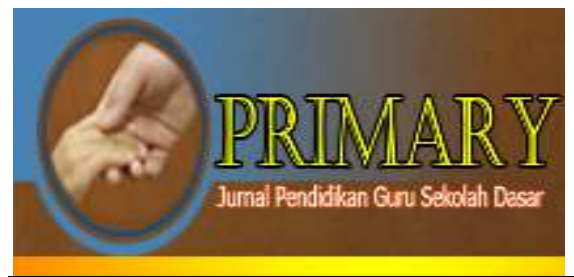

\author{
PRIMARY: JURNAL PENDIDIKAN GURU SEKOLAH DASAR \\ VOLUME 10 NOMOR 3 JUNI 2021 \\ ISSN : 2303-1514 | E-ISSN : 2598-5949 \\ DOI : http://dx.doi.org/10.33578/jpfkip.v10i3.8123 \\ https://primary.ejournal.unri.ac.id/index.php/JPFKIP
}

\title{
ANALYZING THE CONTENT OF HISTORY MATERIALS IN THE 2013 CURRICULUM INTEGRATED THEMATIC BOOK FOR PRIMARY SCHOOLS (SD/MI)
}

\author{
Arif Widodo $^{1}$, Dyah Indraswati ${ }^{2}$ \\ ${ }^{1,2}$ Program Studi Pendidikan Guru Sekolah Dasar, Universitas Mataram, Indonesia \\ arifwidodo@unram.ac.id,dyahindraswati@unram.ac.id
}

\section{ANALISIS MUATAN MATERI SEJARAH DALAM BUKU TEMATIK TERPADU SD/MI KURIKULUM 2013}

\begin{tabular}{|c|c|}
\hline ARTICLE HISTORY & $\overline{\text { ABSTRACT }}$ \\
\hline $\begin{array}{l}\text { Submitted: } \\
18 \text { Desember } 2020 \\
18^{\text {th }} \text { December } 2020\end{array}$ & $\begin{array}{l}\text { Abstract: The content of history materials should not be ignored in learning at elementary } \\
\text { schools. However, in reality, history has always been regarded as a second-level lesson that is } \\
\text { not very important. One of the causes is the teacher's ignorance of the educational values } \\
\text { contained in the content of history materias. This study aimed to analyze history content in } \\
\text { SD/MI thematic books. The object of this study was the } 2013 \text { curriculum integrated thematic } \\
\text { book revised edition of } 2017 / 2018 \text {. The method in this study was content analysis. The values } \\
\text { found in the content of history materials at elementary schools included educational, } \\
\text { instructive, recreational, and inspirational values. These values were contained in theme } 5 \text { "my, } \\
\text { hero" at grade IV, theme } 7 \text { "events in life" at grade V, and theme } 3 \text { "figures and inventions" } \\
\text { at grade VI. In addition,, several character values were also found including heroism, } \\
\text { nationalism, cooperation, unyielding, vigilant, and willingness to sacrifice for the sake of } \\
\text { people. This study demonstrated the benefits of studying history for students. The } 2013 \\
\text { curriculum integrated thematic book was very suitable to be used as a medium in studying } \\
\text { history material at elementary school. }\end{array}$ \\
\hline
\end{tabular}

Keywords: thematic books, history contents, educational value, SD/MI

Accepted:

10 Mei 2021

$10^{\text {th }}$ May 2021

Abstrak: Muatan materi sejarah tidak boleh dilupakan dalam pembelajaran di sekolah dasar. Realitanya, sejarah selalu dianggap sebagai pelajaran level kedua yang tidak terlalu penting. Salah satu penyebabnya adalah ketidaktahuan guru terhadap nilai-nilai edukasi yang terdapat dalam muatan materi sejarah. Penelitian ini bertujuan untuk menganalisis konten sejarah dalam buku tematik SD/MI. Objek kajian dalam penelitian ini adalah buku tematik terpadu kurikulum 2013 edisi revisi 2017/2018. Metode yang digunakan adalah analisis konten. Nilainilai yang ditemukan dalam muatan materi sejarah di sekolah dasar, antara lain: nilai edukatif, instruktif, rekreatif, dan nilai inspiratif. Nilai-nilai tersebut termuat dalam tema 5 " pahlawanku" di kelas IV, tema 7 "peristiwa dalam kehidupan" di kelas V, dan tema 3 "tokoh dan penemuan di kelas VI. Selain empat nilai utama tersebut juga ditemukan beberapa nilai

Published:

26 Juni 2021

$26^{\text {th }}$ June 2021 karakter, antara lain: kepahlawanan, nasionalisme, kerjasama, pantang menyerah, waspada, dan rela berkorban demi kepentingan orang banyak. Penelitian ini menunjukkan betapa besarnya manfaat belajar sejarah bagi siswa. Buku tematik terpadu kurikulum 2013 sangat layak digunakan sebagai media dalam mempelajari materi sejarah di sekolah dasar.

Kata Kunci: buku tematik, muatan sejarah, nilai edukasi, SD/MI

\section{CITATION}

Widodo., A., \& Indraswati., D. (2021). Analyzing the Content of History Materials in the Integrated Thematic Book for Primary Schools (SD/MI) in the 2013 Curriculum. Primary: Jurnal Pendidikan Guru Sekolah Dasar, 10 (3), 590-603. DOI: http://dx.doi.org/10.33578/jpfkip.v10i3.8123 . 


\section{PENDAHULUAN}

Sejarah merupakan pelajaran hidup bagi manusia. Melalui sejarah manusia dapat belajar tentang kesuksesan ataupun kegagalan dimasa lalu. Manusia dapat mengambil pelajaran dari sejarah untuk mendapatkan masa depan yang lebih baik (Takayama, 2020). Pada hakekatnya belajar sejarah tidak hanya tentang masa lalu, tetapi belajar untuk kehidupan di masa yang akan datang. Maka dari itu setiap siswa harus diajarkan tentang sejarah sejak dini, terutama sejarah perjuangan bangsanya. Ironisnya masih banyak masyarakat yang menganggap bahwa sejarah itu tidak penting, terlebih lagi pada jenjang sekolah dasar. Terdapat anggapan bahwasannya pembelajaran di sekolah dasar yang terpenting adalah baca tulis dan berhitung. Hal ini sungguh ironis mengingat di dalam sejarah terdapat nilai-nilai karakter untuk membentuk perilaku siswa. Cara pandang terhadap materi sejarah harus dirubah (Komatsu \& Rappleye, 2020). Terlebih lagi usia sekolah dasar merupakan usia emas. Pada usia emas tersebut karakter dan perilaku sosio-emosional siswa lebih mudah dibentuk. Terdapat berbagai macam cara dalam mengimplementasikan pendidikan karakter, salah satunya melalui pembelajaran sejarah. Hal ini tidaklah berlebihan mengingat dalam materi sejarah terdapat muatan-muatan nilai karakter antara lain nasionalisme, semangat persatuan, semangat perjuangan, kerja keras, dan gotong royong. Selain itu masih banyak lagi nilai-nilai karakter yang dapat diambil dari sejarah yaitu pentingya sebuah proses.

Sejarah adalah peristiwa masa lalu yang tidak akan terulang lagi. Sejarah menyimpan kenangan kebesaran dan kejayaan di masa lalu. Melalui sejarah manusia dapat belajar dari pengalaman. Bung Karno pernah berpesan "Jasmerah" jangan sekali-kali melupakan sejarah. Ada apa dengan sejarah sehingga bung Karno berkata demikian? Sejarah adalah karakter dan jati diri bangsa. Sejarah telah mengajarkan bahwa tidak ada keberhasilan tanpa adanya perjuangan (Jacobs
\& Templin, 2020). Perjuangan merupakan sebuah proses yang panjang serta membutuhkan kegigihan dan pengorbanan. Kemerdekaan yang diraih oleh bangsa Indonesia tidak datang secara tiba-tiba. Belajar dari kegagalan, perlawanan yang bersifat sporadis harus dipersatukan. Kemerdekaan tidak akan tercapai tanpa adanya semangat persatuan. Maka dari itu setiap siswa dapat belajar tentang arti penting persatuan melalui sejarah. Sejarah juga telah mencatat bahwa menjaga persatuan sebuah bangsa tidaklah mudah. Tidak sedikit kerajaan atau negara besar hancur karena masalah ini. Kerajaan sebesar Majapahit dapat hancur karena tidak dapat menjaga persatuan (Akbar, 2014). Tidak hanya kerajaan Majapahit, negara-negara di era modern sekalipun dapat hancur karena perpecahan. Uni Soviet dan Yugoslavia merupakan contoh negara modern yang hancur karena tidak dapat menjaga persatuan dan kesatuan bangsanya (Rexhepi, 2020). Perjalanan sejarah nusantara telah menggambarkan bahwa mempersatukan nusantara ke dalam satu visi menjadi negara nasional bukanlah perkara yang mudah. Oleh karena itu, penting mempelajari sejarah perjuangan bangsa agar siswa dapat mengetahui arti penting dari perjuangan.

Pernyataan di atas menggambarkan betapa pentingnya mempelajari sejarah. Oleh karena itu sejarah harus diajarkan sejak dini kepada siswa mulai dari sekolah dasar hingga perguruan tinggi. Guru harus dipersiapkan menjadi pengajar sejarah yang handal di masa depan (Yarmatov \& Qizi, 2020). Terlebih lagi pada jenjang sekolah dasar siswa mempunyai daya ingat yang kuat, sehingga apa yang dipelajarinya akan terekam dalam ingatannya. Permasalahannya adalah jika siswa tidak diajari sejarah maka ia akan mudah dibohongi dengan sejarah yang salah. Jika pemuda telah disesatkan dengan pengetahuan sejarah yang salah maka tunggulah saat kehancurannya (Suryanegara, 2014). Pemuda yang tidak tahu dengan sejarah bangsanya akan mudah terombang ambing tanpa jati diri. Terdapat 
pendapat dari orang bijak yang menyatakan 'jika ingin menghancurkan suatu bangsa, maka hancurkanlah ingatan pemuda akan sejarah bangsa itu. Hal inilah yang telah dilakukan oleh Belanda dalam merusak karakter bangsa kita dahulu dengan membuat tukang cerita keliling. Tukang dongeng ini digaji oleh Belanda untuk membuat cerita masa lalu yang tujuannya adalah menyesatkan fakta sejarah. Kebesaran bangsa nusantara dan kemuliaan budi para leluhur telah dijungkir balikkan (Anto \& Nuraini, 2020). Salah satu tujuan utamanya adalah menciptakan kebencian dan permusuhan. Implikasinya adalah kebenaran sejarah menjadi kabur dan kebanggaan terhadap kejayaan masa lalu menjadi luntur.

Berawal dari pernyataan di atas maka perlu dilakukan kajian terhadap konten sejarah yang diajarkan dalam buku ajar kurikulum 2013. Penelitian ini bertujuan untuk mengetahui apakah buku tematik terpadu terbitan kementrian pendidikan dan kebudayaan telah mencantumkan muatan materi sejarah. Penelitian ini penting dilakukan mengingat buku ajar yang diterbitkan Kementrian Pendidikan dan Kebudayaan menjadi rujukan utama bagi siswa SD/MI. Maka dari itu buku ajar perlu mendapat kritikan dan masukan melalui sebuah penelitian. Melalui penelitian ini diharapkan dapat memberikan saran untuk perbaikan dalam penyusunan buku ajar di sekolah dasar. Masalah utama yang dikaji dalam penelitian ini antara lain: apakah buku tematik terpadu kurikulum 2013 telah memuat konten sejarah? pada tema apa saja konten sejarah dapat ditemukan? Nilai-nilai apa saja yang termuat dalam konten sejarah?

\section{KAJIAN TEORI \\ Hakekat sejarah}

Sejarah merupakan salah satu rumpun ilmu sosial yang harus diajarkan kepada setiap siswa. Berbeda dengan bidang ilmu sosial lain, ruang linkup materi sejarah adalah peristiwa masa lampau (Madjid \& Wahyudhi, 2014). Sejarah tidak hanya cerita nenek moyang tanpa makna. Terdapat banyak hal yang dapat digali dalam peristiwa sejarah. Mempelajari sejarah yang benar dapat menghindarkan anak bangsa dari kekaburan fakta. Terdapat sebuah pendapat yang menyatakan bahwa jika ingin menghancurkan suatu bangsa, maka hapuskanlah ingatan sejarah para pemudanya. Pernyataan tersebut mengandung makna bahwa dalam pembelajaran sejarah terdapat banyak kepentingan, baik yang bernuansa positif maupun negatif. Masa lalu adalah sejarah sedangkan masa depan adalah politik. Salah satu hal yang paling ditakutkan dalam penulisan sejarah dengan kepentingan tertentu adalah timbulnya distorsi sejarah. Jika sejarah telah diputarbalikkan dan pengaburan kebenaran terjadi maka kehancuran bangsa semakin dekat. Rasa bangga pada pahlawan dan sikap nasionalisme akan hilang. Apa yang terjadi di masa lalu memiliki keterkaitan yang erat dengan masa depan. Sejarah memiliki andil yang sangat besar terhadap kelangsungan hidup suatu bangsa. Maka dari itu visi utama Sejarah nasional adalah membentuk karakter cinta tanah air. Kartodirdjo, (1992) mengungkapkan bahwa penulisan sejarah hendaknya menggunakan pendekatan Indonesiasentris meninggalkan penulisan sejarah lama yang Eropasentris. Sejarah Eropasentris disusun oleh kaum kapitalis yang bertujuan untuk menghancurkan dan mengadu domba. Maka dari itu dalam memilih bahan ajar sejarah harus selektif. Pembelajaran pada jenjang sekolah dasar harus lebih ditekankan pada dimensi pedagogik dalam pembentukan karakter moral. Berawal dari sini telah nyata bahwa sejarah mempunyai peran yang sangat besar dalam membentuk karakter siswa. Sejarah yang diajarkan di sekolah dasar harus mencerminkan nilai-nilai karakter karakter dan kepentingan bangsa yaitu cinta tanah air.

\section{Pembelajaran sejarah di SD/MI}

Materi sejarah pada jenjang sekolah dasar tidak diajarkan secara terpisah, melainkan terintegrasi dalam pembelajaran IPS (Rachmah, 2014). Kompetensi dasar mata pelajaran IPS disusun secara proporsional 
dengan mempertimbangkan keberadaan ilmuilmu sosial lainnya, yaitu: sosiologi, ekonomi, geografi, psikologi dan antropologi. Pembelajaran ilmu-ilmu sosial tersebut terintegrasi dan terpadu dalam pembelajaran IPS. Berdasarkan rumusan yang disepakati oleh pengurus Himpunan Dosen PGSD Indonesia di Makasar pada bulan Maret 2020 dapat diketahui bahwa bahan kajian IPS pada jenjang sekolah dasar terdiri dari Sejarah, Geografi, Ekonomi, Sosiologi, Antropologi, Politik dan Hukum, serta Psikologi Sosial (HDPGSDI, 2020). Perumusan Profil dan CPL yang dihadiri oleh seluruh peserta dari seluruh Indonesia menghasilkan kesepakatan bahwa dalam aspek pengetahuan maupun umum capaian lulusannya adalah mampu menguasai dan menerapkan lima bidang keahlian, salah satunya adalah IPS yang di dalamnya termuat materi sejarah. Seiring dengan adanya perubahan kurikulum mata pelajaran IPS tidak lagi diajarkan terpisah, tetapi dipadukan dengan mata pelajaran yang lain (Permatasari, 2014). Jika hanya dilihat sekilas, tidak terlihat jelas batasan antara mata pelajaran satu dengan yang lain. Maka dari itu tidak mengherankan jika ada anggapan bahwa sudah tidak ada bidang studi di sekolah dasar, termasuk di dalamnya adalah mata pelajaran IPS. Jika dianalisis lebih mendalam pada hakekatnya mata pelajaran di SD masih dapat diidentifikasi dengan, meskipun materi telah dikemas secara tematik (Widodo, 2020).

\section{Buku Tematik Terpadu}

Buku tematik terpadu merupakan bahan ajar yang dipersiapkan kementrian pendidikan dan kebudayaan untuk mempermudah implementasi kurikulum 2013. Hingga saat ini buku tematik merupakan rujukan utama dan bahkan satu-satunya dalam pembelajaran mulai dari kelas I hingga kelas VI. Sesaat setelah buku tematik diluncurkan penggunaanya telah meluas ke seluruh pelosok negeri. Terdapat perubahan yang sangat mendasar dalam pengemasan bahan ajar pada buku tematik. Pada awalnya mata pelajaran disajikan secara terpisah, namun pada buku tematik mata pelajaran dipadukan secara terintegrasi. Pendekatan tematik telah mengaburkan keberadaan masing-masing mata pelajaran. Walaupun kemasan materi dalam buku ajar telah disajikan secara tematik tetapi tidak mengurangi esensi dari kelima bidang studi di sekolah dasar. Keterpaduan dalam penyajian materi ajar bertujuan agar siswa dapat memahami secara utuh dan konkrit serta keterkaitan antara materi yang dipelajari dengan kehidupan nyata (Hernawan, Resmini, \& Andayani, 2011).

\section{METODE PENELITIAN}

Penelitian ini dirancang dalam bentuk penelitian deskriptif kualitatif. Subjek penelitian berupa buku ajar kurikulum 2013 untuk SD/MI revisi 2017/2018. Buku tematik yang dianalis adalah buku tematik kelas IV sampai dengan kelas VI. Instrumen yang digunakan dalam penelitian ini berupa rubrik. Rubrik digunakan untuk melakukan pengkodean terhadap tema yang terdapat dalam buku tematik. Teknik pengumpulan data dilakukan dengan dokumentasi. Data yang telah terkumpul dianalisis dengan metode analisis konten. Melalui analisis ini materi dalam buku ajar dianalisis secara detail untuk mencari muatan materi sejarahnya. Tahapan penelitian terdiri dari pengumpulan data, analisis data dan penerikan kesimpulan. Pada tahap pengumpulan data terlebih dahulu dilakukan analisis multikonteks yang bertujuan untuk memilah mana saja konten yang bermuatan IPS. Setelah muatan IPS ditemukan selanjutnya dilakukan analisis terhadap muatan materi sejarah pada tema IPS. Pada tahap selanjutnya dilakukan tabulasi sebaran materi sejarah pada masing-masing tema. Muatan materi sejarah yang ditemukan selanjutnya dianalisis nilai-nilai yang terdapat di dalamnya. Keabsahan temuan dilakukan melalui diskusi dengan guru SD selaku pengguna buku ajar di lapangan. Berikut ini salah satu rubrik yang digunakan untuk mendata muatan materi sejarah dalam buku tematik sekolah dasar pada masing-masing 
kelas.

Tabel 1. Rubrik Pengumpulan Data

\begin{tabular}{lcc}
\hline \multicolumn{1}{c}{ Tema } & Terdapat Muatan IPS & Terdapat Muatan Sejarah \\
\hline 1. Indahnya kebersamaan & $\sqrt{ }$ & \\
2. Selalu berhemat energi & & \\
3. Peduli terhadap makhluk hidup & $\sqrt{ }$ & $\sqrt{ }$ \\
4. Berbagai pekerjaan & $\sqrt{ }$ \\
5. Pahlawanku & \\
6. Cita-citaku & $\sqrt{ }$ \\
7. Indahnya keragaman di negeriku & $\sqrt{ }$ \\
8. Daerah tempat tinggalku & $\sqrt{ }$ \\
9. Kayanya negeriku & \\
\hline
\end{tabular}

\section{HASIL DAN PEMBAHASAN}

Hasil yang didapatkan dalam penelitian ini adalah deskripsi sebaran tema yang mengandung muatan konten sejarah dan nilai-nilai yang terdapat pada masing tema. Berdasarkan analisis terhadap buku tematik di kelas IV hingga kelas VI dapat diketahui bahwa materi sejarah telah disajikan secara proporsional pada beberapa tema. Konten muatan sejarah ditinjau dari sisi tema dan dari sisi kandungan materi yang terdapat pada tema IPS. Jumlah tema dalam buku siswa dari kelas IV sampai dengan kelas VI adalah 27 tema. Masing-masing kelas memiliki 9 tema yang diberikan pada semester I dan semesater II. Tema 1 sampai dengan tema 5 disajikan pada semester I, sedangkan tema 6 sampai dengan tema 9 disajikan pada semester 2. Dari jumlah tema tersebut tema yang mengandung muatan IPS sebanyak 6 tema di kelas IV, 2 tema di kelas V dan 5 tema di kelas VI. Tema tersebut antara lain "Indahnya Kebersamaan", "Kayanya Negeriku", "Pahlawanku", "Indahnya Keragaman Di Negeriku", "Daerah Tempat Tinggalku", dan "Berbagai Pekerjaan", tema-tema tersebut diberikan pada kelas IV. Tema yang mengandung muatan materi IPS di kelas V antara lain tema "Lingkungan Sahabat Kita" dan "Peristiwa Dalam Kehidupan". Untuk di kelas VI tema yang mengandung muatan IPS adalah "Kepemimpinan", "Tokoh dan Penemuan", "Globalisasi", "Wirausaha", dan "Persatuan Dalam Perbedaan".

\section{Konten Sejarah Dalam Buku Tematik Terpadu}

Pada buku tematik kurikulum 2013 materi IPS disajikan secara terpadu dengan mata pelajaran yang lain. Muatan materi IPS dapat dikenali melalui tema-tema yang merujuk pada Kompetensi Dasar (KD) mata pelajaran IPS. Tema yang mengandung muatan sejarah dapat dianalisis pada tema-tema IPS tersebut. Jumlah tema yang memuat materi sejarah sebanyak 3 tema. Tema tersebut tersebar mulai dari kelas IV hingga kelasVI. Untuk di kelas IV tema yang mengandung muatan sejarah adalah tema 5 "Pahlawanku", yang terdiri dari subtema: Perjuangann para pahlawan, pahlawan kebanggaanku, dan sikap kepahlawanan. Tema sejarah di kelas V terdapat pada tema 7 "Peristiwa dalam kehidupan". Tema tersebut dibagi menjadi beberapa subtema antara lain peristiwa kebangsaan masa penjajahan, peristiwa kebangsaan seputar proklamasi kemerdekaan, dan peristiwa mengisi kemerdekaan. Tema sejarah di kelas VI terdapat pada tema 3 yaitu "Tokoh dan penemuan". Tema tersebut dibagi menjadi beberapa subtema antara lain penemu yang mengubah dunia, penemu dan manfaatnya, dan ayo menjadi penemu.

Penyajian materi telah terintegrasi satu sama lain, namun demikian muatan materi pada subbidang ilmu masih dapat terdeteksi. Hal ini berlaku juga untuk menganalisis muatan materi sejarah pada tema IPS. Melalui analisis konten dapat diketahui kandungan 
ilmu-ilmu sosial yang terdapat pada tema-tema IPS. Berikut ini disajikan konten sejarah yang berada pada bidang studi IPS jika dibandingkan dengan subbidang studi ilmu sosial yang lain.

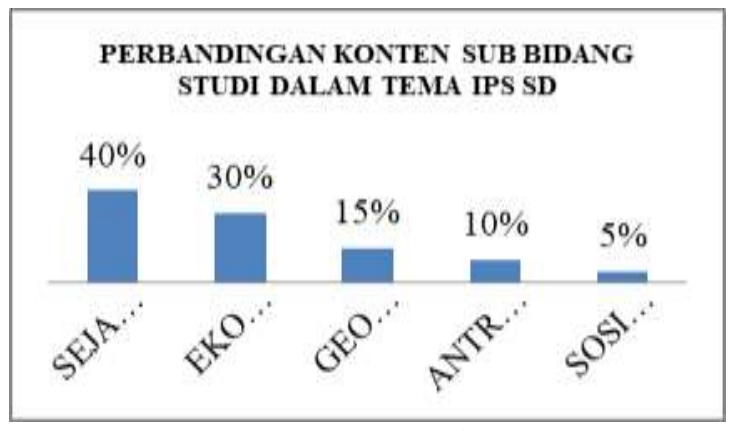

Sumber: Data primer

Gambar 1. Perbandingan Muatan Subbidang Studi dalam Buku Tematik SD

Berdasarkan gambar di atas dapat diketahui bahwa muatan materi sejarah paling banyak dijumpai dalam buku tematik SD. Jumlah tersebut sangat mendominasi dengan jumlah $40 \%$ dari konten IPS di SD. Subbidang ilmu sosial yang termuat dalam tema IPS SD adalah ekonomi dengan jumlah $30 \%$ dari keseluruhan tema. Subbidang ilmu geografi menempati urutan ketiga dengan jumlah $15 \%$. Subbidang ilmu antropologi dan sosiologi menempati urutan terakhir dengan jumlah masing-masing $10 \%$ dan $5 \%$. Data tersebut menggambarkan bahwa muatan materi sejarah yang terdapat dalam buku tematik terpadu jika dibandingkan dengan subbidang ilmu sosial lain paling banyak disajikan. Hal ini menunjukkan bahwa konten sejarah dalam buku tematik terpadu masih mendapatkan porsi yang cukup besar dalam penyusunan materi.

Nilai manfaat sejarah dalam buku tematik
Belajar sejarah memiliki banyak manfaat, mulai dari manfaat edukatif, instruktif, rekreatif dan inspiratif. Berikut ini dapat disajikan nilai manfaat muatan materi sejarah pada masing-masing tema. Tema pertama yang dianalisis adalah "Pahlawanku", tema 5 di kelas IV. Terdapat banyak nilai-nilai yang dikembangkan dalam tema "Pahlawanku". Nilai-nilai yang dikembangkan dalam subtema "Perjuangan para pahlawan" antara lain menolong orang lain dengan ikhlas, berani dan gigih. Nilai-nilai tersebut merupakan cermin nilai yang dimiliki oleh para pahlawan bangsa. Nilai lain yang dikembangkan yaitu mendahulukan kepentingan orang lain. Mendahulukan kepentingan orang lain merupakan cermin dari pengamalan Pancasila sila keempat. Maka dari itu secara tidak langsung nilai-nilai yang dikembangkan ini telah mencerminkan nilainilai Pancasila. 


\section{PRIMARY: JURNAL PENDIDIKAN GURU SEKOLAH DASAR \\ VOLUME 10 NOMOR 3 JUNI 2021 \\ ISSN : 2303-1514 | E-ISSN : 2598-5949 \\ DOI : http://dx.doi.org/10.33578/jpfkip.v10i3.8123 \\ https://primary.ejournal.unri.ac.id/index.php/JPFKIP}

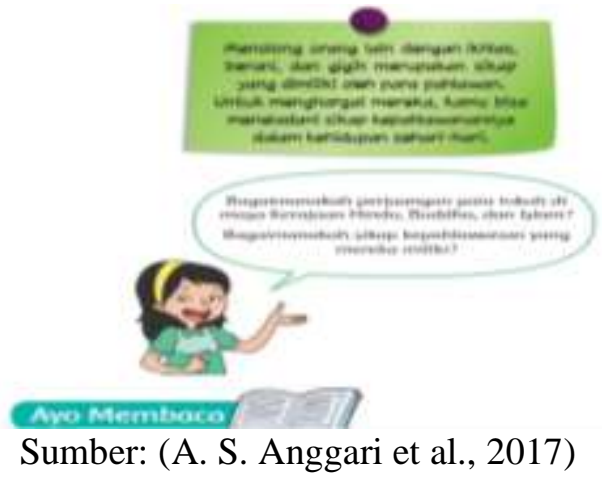

Gambar 2. Salah Satu Nilai Karakter yang Dikembangkan pada Tema Pahlawanku

Nilai selanjutnya yang dikembangkan dalam tema Pahlawanku adalah nilai rekreatif. Siswa diajak untuk menjelajah keindahan dengan menembus batasan waktu. Siswa dapat menikmati keindahan peninggalan sejarah melalui aktivitas ayo membaca. Melalui pengembangan nilai karakter ini siswa dapat menghargai jasa para pahlawan dan peninggalan bersejarah dari para leluhur. Nilai- nilai ini akan melahirkan kesadaran para siswa untuk melestarikan dan merawat peninggalan sejarah di lingkungan masing-masing. Melalui peninggalan benda bersejarah siswa juga dapat menikmati keindahan. Hal ini bermanfaat untuk mengembangkan kemampuan siswa dalam hal estetika.

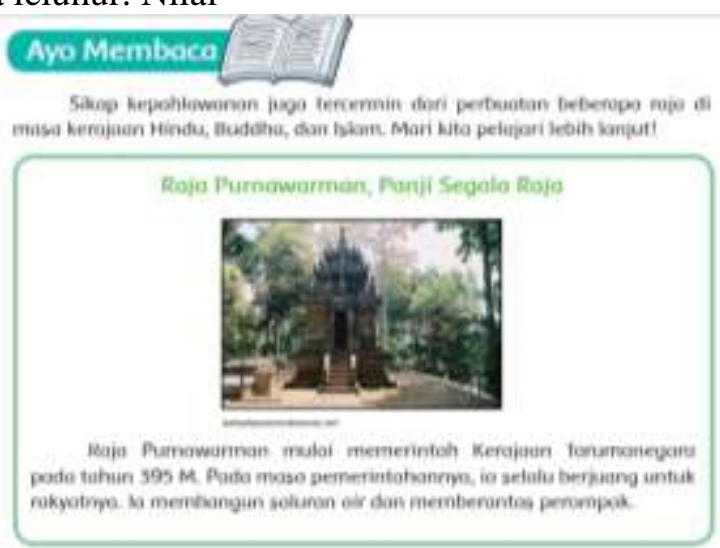

Sumber: (A. S. Anggari et al., 2017)

Gambar 3. Nilai rekreatif dalam tema Pahlawanku

Pada pembelajaran ketiga, nilai-nilai yang dikembangkan antara lain meneladani sikap-sikap kepahlawanan, antara lain suka menolong, pantang menyerah, semangat kejuangan, kepemimpinan, dan kebijaksanaan serta nilai-nilai estetika. Pada pembelajaran kelima yang dikembangkan adalah nilai kepahlawanan keikhlasan, berjuang tanpa pamrih, gigih dalam berjuang, semangat berkorban, keteladanan, dan sungguh-sungguh dalam meraih cita-cita. Materi yang dipelajari pada tema ini adalah kisah Gajah Mada dalam mempersatukan nusantara. Semangat perjuangan, pengorbanan dan keikhlasan Gajah Mada patut ditiru oleh para "Gajah Mada" milleneal dalam berjuang meraih cita-cita.

Subtema 2 "pahlawan kebanggaanku", nilai-nilai yang dikembangkan adalah nilai yang mencerminkan kepada rasa bangga terhadap para pahlawan. Pada bagian 
pembelajaran kedua terdapat konten yang sangat menarik yaitu adanya sajian yang menghubungkan antara nilai kepahlawanan dengan peristiwa sekarang. Nilai kepahlawanan yang dikembangkan yaitu semangat dan kerja keras dalam meraih citacita. Perjuangan dalam meraih cita-cita yang dilakukan oleh tokoh dalam gambar terinspirasi oleh perjuangan para pahlawan dalam meraih kemerdekaan. Pada pembelajaran 2 juga mengembangkan nilainilai kebersamaan, gotong royong, dan persatuan dalam meraih cita-cita. Dibutuhkan kerjasama yang kuat agar perjuangan dapat membuahkan hasil. pada pembelajaran kelima nilai yang dikembangkan adalah peduli lingkungan sekitar. Melalui pembelajaran pada tema ini siswa dapat belajar bahwa nilai-nilai kepahlawanan tidak hanya terjadi pada masa lampau, tetapi dapat diaktualisasikan dalam kehidupan sehari-hari.

Belajar sejarah pada hakekatnya belajar tentang masa lampau. Namun demikian, buka berati sejarah tidak dapat berulang (Clifton \& Damon, 2020). Terdapat pola yang sama dalam pergerakan sejarah, yang membedakan hanya waktu dan tokoh peristiwa itu terjadi. Maka dari itu dalam mempelajari sejarah harus dikaitkan dengan peristiwa masa kini. Jika sejarah tidak dikaitkan dengan permasalahan dimasa kini maka sejarah tidak akan bermakna (Hein \& van Dooren, 2020). Hal ini sesuai dengan manfaat sejarah berfungsi instruktif. Materi sejarah dapat dijadikan bahan pembelajaran pada masa kini. Berdasarkan hasil analisis terhadap tema yang bermuatan sejarah dapat ditemukan beberapa nilai instruktif dalam buku tematik. Salah satu diantaranya terdapat pada subtema "sikap kepahlawanan". Pada tema tersebut disajikan bahan bacaan terkait dengan benda peninggalan bersejarah dari tokoh pejuang kemerdekaan "Bung Tomo". Benda peninggalan Bung Tomo yang dijadikan bahan pelajaran pada subtema ini adalah mobil merk Opel Kapitan. Salah satu keunikan mobil merk ini adalah spion yang dimiliki hanya satu. Letak keterkaitan antara benda bersejarah ini dengan kehidupan sekarang adalah fungsi kaca spion. Melalui kaca spion dalam benda bersejarah ini siswa dapat belajar tentang konsep bayangan dan macam-macam bentuk dan fungsi cermin. Penggunaan benda bersejarah sebagai sumber belajar menunjukkan bahwa benda bersejarah dapat berfungsi instruktif. Hal ini membuktikan bahwa masa lampau dengan masa kini dapat dikaitkan dengan cara sederhana yaitu melalui bahan pembelajaran.

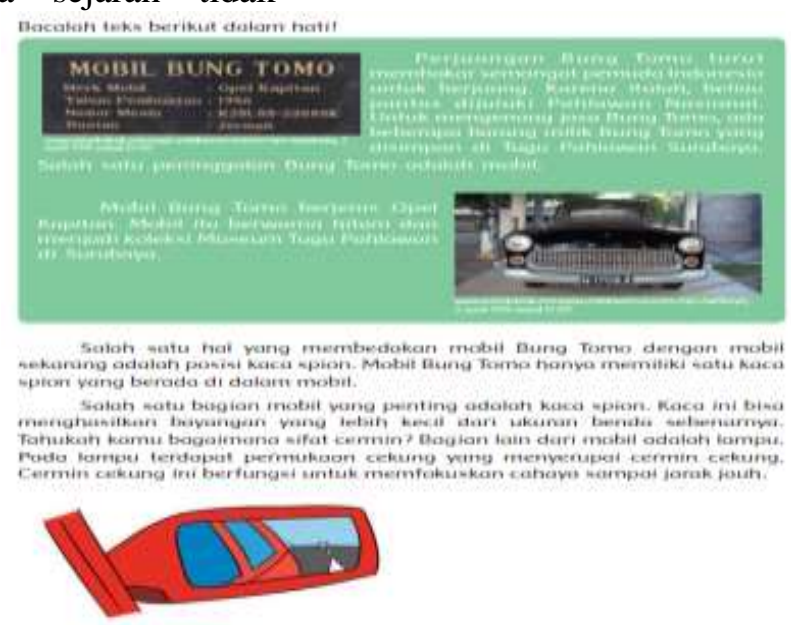

Sumber: (A. S. Anggari et al., 2017)

Gambar 4. Nilai Instruktif 
Nilai terpenting yang dikembangkan pada subtema 3 "sikap kepahlawanan", nilainilai karakter yang termuat pada tema tersebut antara lain: keberanian dan pengorbanan. Pada subtema ini siswa belajar tentang sikap kepahlawanan yang ditunjukkan oleh para pahlawan. Pada aktivitas "Ayo mengamati" siswa diberi tugas untuk menganalisis perjuangan para pahlawan. Melalui aktvitas ini siswa dapat merasa bangga dengan perjuangan para pahlawan. Rasa bangga terhadap jasa para pahlawan merupakan salah satu sikap yang harus dikembangkan agar siswa dapat menghargai orang lain. Aktivitas pengerjaan tugas secara berkelompok mengandung nilainilai karakter persatuan dalam perbedaan. Melalui kerja kelompok siswa dapat bekerjasama dan saling menghargai pendapat. Nilai kerjasama ini mencerminkan persatuan dan kesatuan yang terdapat pada Pancasila. Selain itu salah satu nilai edukasi dalam subtema "sikap kepahlawanan" adalah setiap orang dapat menjadi pahlawan. Hal ini telah termuat pada pembelajaran 6 pada aktivitas ayo membaca dengan judul wacana "Kakek Penyelamat Lingkungan Tanpa Pamrih". Nilai kepahlawanan yang ditunjukkan oleh kakek dalam wacana tersebut adalah berbuat kebaikan yang bermanfaat untuk kelestarian lingkungan dan manusia. Sikap kepahlawanan yang dilakukan oleh kakek tersebut patut dihargai dan dijadikan teladan oleh setiap siswa. Esensi dari wacana tersebut adalah berbuat baik tidak harus menunggu kaya, tetapi dapat dilakukan kapan saja asalkan ada kemauan dan kesadaran untuk berbuat yang bermanfaat. Melalui sikap dan perilaku seperti ini setiap orang dapat menjadi pahlawan, sesuai dengan kapasitas dan kapabilitas yang dimiliki.

Belajar sejarah tidak hanya belajar tentang dongeng tanpa makna. Substansi belajar sejarah adalah belajar dari masa lalu. Sejarah mengandung nilai-nilai edukasi. Sejarah mengandung pelajaran yang sangat berharga untuk kehidupan yang akan datang. Salah satu contoh nilai edukasi yang termuat dalam sejarah tema "Peristiwa dalam kehidupan" di kelas V adalah kewaspadaan. Nilai tersebut termuat pada pembelajaran 3 subtema "peristiwa kebangsaan masa penjajahan". Pada subtema tersebut disajikan sebuah bacaan dengan judul "Reaksi rakyat Indonesia terhadap Pemerintah Kolonial". Bacaan tersebut menjelaskan bahwa kaum penjajah pada awalnya datang dengan cara baik-baik, namun lambat laun mereka mulai ingin menancapkan kekuasaan. Berbagai tipu daya dilakukan kaum penjajah untuk menguasai seluruh nusantara. Peristiwa ini mengandung pelajaran agar bangsa Indonesia selalu waspada. Terlebih lagi siswa sebagai generasi penerus bangsa harus waspada dengan segala macam upaya bangsa asing untuk berkuasa lagi di Indonesia. Bentuk penjajahan baru patut diwaspadai dengan cara mencintai produk dalam negeri dan tidak mudah percaya dengan bangsa asing. Tidak dapat dipungkiri, dalam sejarah penaklukan selalu mempergunakan berbagai cara agar tujuan dapat tercapai (Stein, 2020). Maka dari itu siswa harus diajarkan agar tidak lengah terhadap tipu daya bangsa asing yang dewasa ini semakin terlihat nyata. 


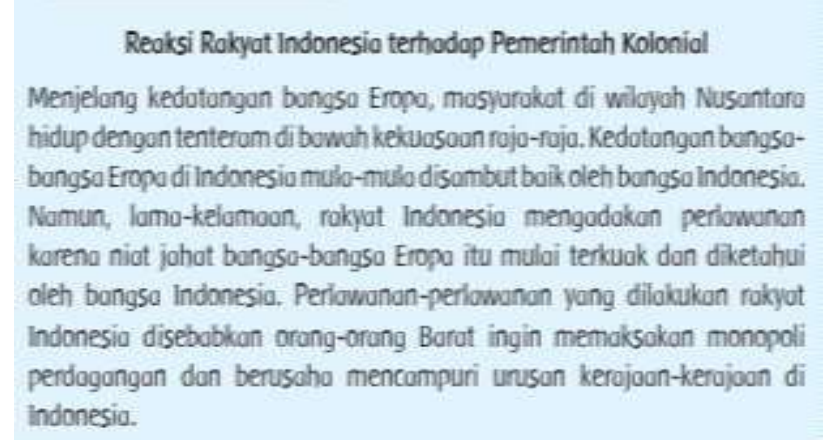

Sumber: (Maryanto, Fransiska, Kusumawati, Puspa, \& Subekti, 2017)

Gambar 5. Nilai Edukasi dalam Sejarah

Nilai edukasi yang terdapat pada tema "Peristiwa dalam kehidupan" masih banyak sekali. Salah satunya yang terdapat pada pembejaran 4 subtema "Peristiwa Kebangsaan Masa Penjajahan". Pada subtema tersebut disajikan bacaan tentang gagalnya upaya perjuangan bangsa Indonesia dalam melawan penjajah. Kegagalan demi kegagalan yang dialami oleh para pejuang salah satu penyebabnya adalah tidak adanya rasa persatuan antar daerah yang berjuang. Perjuangan dilakukan secara kedaerahan dengan mengandalkan tokoh tertentu. Ketergantungan pada satu tokoh membuat perlawanan rakyat lebih mudah dipadamkan. Belum ada organisasi yang dapat menyatukan berbagai kelompok yang sedang berjuang. Belajar dari kegagalan yang dilakukan oleh pejuang terdahulu menginspirasi para tokoh muda untuk membuat organisasi perjuangan. Salah satu misi dari organisasi ini adalah mempersatukan berbagai kelompok untuk berjuang bersama-sama. Berdasarkan pembelajaran pada tema ini siswa dapat belajar tentang pentinya persatuan dan kesatuan bangsa. Kegagalan bangsa Indonesia dalam berjuang secara sporadis harus menjadi pelajaran bagi siswa bahwa persatuan itu penting. "Bersatu kita teguh, bercerai kita runtuh" merupakan peribahasa yang tepat untuk menggambarkan pentingnya persatuan. Maka dari itu setiap diri siswa harus ditanamkan rasa cinta tanah air dengan menjaga perdamaian agar persatuan dan kesatuan bangsa tetap terjaga. Membiasakan siswa untuk kerja kelompok merupakan salah satu upaya yang dapat dilakukan guru dalam membentuk karakter siswa agar terbiasa bekerjasama. Melalui metode seperti ini siswa tidak akan merasa canggung jika harus bekerja dalam tim. Segala sesuatu yang dilakukan secara bersama-sama akan terasa lebih ringan dan permasalahan sulit akan terasa lebih mudah.

Nilai manfaat belajar sejarah yang tidak kalah penting adalah nilai inspiratif. Sejarah dalam hal ini berfungsi sebagai sumber inspirasi tentang keberhasilan maupun kegagalan yang dialami oleh tokoh sejarah. Tokoh atau peristiwa bersejarah dapat menjadi ilham dalam menyelesaikan permasalahan kontemporer. Salah satu contohnya adalah keberhasilan Raja Purnawarman dalam membangun saluran irigasi dapat menginspirasi orang sekarang untuk membangun bendungan. Tujuannya adalah agar pengairan ke lahan pertanian dapat lancar dan menghasilkan panen yang berlimpah. Kegagalan yang dialami oleh tokoh sejarah juga dapat menjadi inspirasi orang-orang modern untuk selalu bersemangat dan pantang menyerah. Salah satu tokoh inspiratif yang mengalami banyak kegagalan dalam melakukan uji coba adalah Thomas Alfa Edison. Kisah tokoh ini telah disajikan secara sekilas pada subtema 1 "Penemu yang mengubah dunia" di kelas VI. Pada bagian aktivitas "ayo mencoba" tertulis bahwa 
Thomas Alfa Edison merupakan tokoh yang sering mengalami kegagalan. Tokoh ini telah sering mengalami kegagalan sebelum berhasil menemukan bola lampu. Kisah ini mengajarkan kepada siswa agar tidak pantang menyerah jika mengalami kegagalan. Selalu mencoba hingga berhasil merupakan salah satu inspirasi yang didapatkan dari tokoh bersejarah "Thomas Alfa Edison".

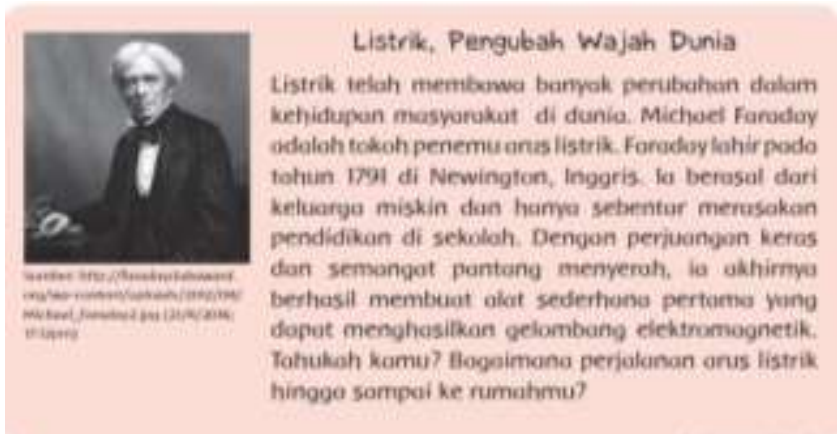

Sumber: (A. St. Anggari et al., 2018)

Gambar 6. Nilai Inspiratif dari Tokoh Sejarah

Sumber inspirasi dalam sejarah tidak hanya berupa keberhasilan atau kegagalan, tetapi juga dapat berasal dari sebuah kondisi. Telah banyak ditemukan dalam catatan sejarah yang berisi tentang keberhasilan tokoh besar walaupun terlahir dalam kondisi yang sulit. Salah satu tokoh inspiratif yang terdapat dalam buku tematik kelas VI adalah Michael Faraday. Kisah tentang tokoh ini disajikan pada subtema pertama pembelajaran pertama. Penemu listrik yang telah mengubah wajah dunia ternyata hanya berasal dari keluarga miskin. Kisah ini harus menjadi inspirasi setiap siswa bahwa bagaimanapun keadaan tidak boleh menjadi alasan untuk tidak berhasil. Setiap keterbatasan yang dimiliki harus diatasi dengan semangat berjuang yang tinggi. Tidak boleh menyerah hanya karena memiliki keterbatasan tertentu. Kisah ini mengajarkan kepada siswa agar selalu semangat dalam belajar meskipun halangan dan rintangan yang dihadapi tidak mudah. Kunci utama keberhasilan adalah semangat dan pantang menyerah.

Berdasarkan hasil analisis terhadap muatan materi dalam buku tematik terpadu dapat terlihat bahwa konten sejarah telah disajikan dengan sangat baik. Konten sejarah telah disajikan secara proporsional pada beberapa tema. Keberadaan konten sejarah masih terlihat jelas meskipun materi telah disajikan secara tematik terpadu. Pengemasan materi sejarah dilakukan dengan model keterpaduan. Salah satu keuntungannya adalah siswa dapat memahami materi secara utuh dan kontekstual. Hal ini dapat dipahami bahwa pada hakekatnya subbidang ilmu tidak dapat dipisahkan, saling terkait satu dengan yang lain (Furinghetti, 2020). Maka dari itu dengan adanya model terpadu yang terdapat pada buku ajar kurikulum 2013 telah memudahkan siswa untuk memahami materi dengan sudut pandang yang luas, holistik dan komprehensif. Siswa dapat mengaitkan antara materi yang satu dengan materi yang lain dengan hanya belajar pada satu tema (Jankvist, Clark, \& Mosvold, 2020).

Konten sejarah yang disajikan dalam buku tematik telah mengandung nilai-nilai manfaat. Nilai-nilai yang terdapat dalam konten sejarah pada buku tematik antara lain nilai edukasi, nilai rekreatif, nilai estetika, nilai instruktif dan nilai inspirasi. Nilai karakter yang ditemukan antara lain nilai kepahlawanan, nilai perjuangan, nilai kerjasama, pantang menyerah, dan nasionalisme. Aktivitas pembelajaran yang 
disajikan telah memfasilitasi siswa untuk mengembangkan karakter. Nilai-nilai yang terdapat dalam materi sejarah jika disajikan secara tepat dapat bermanfaat untuk pengembangan karakter (Widodo, Akbar, \& Sujito, 2017). Salah satu unsur terpenting dalam pembelajaran sejarah adalah pembelajaran yang bermakna, tidak hanya sekedar hafalan (Lim \& Lim, 2020). Maka dari itu dengan belajar sejarah secara tematik siswa lebih mudah menghubungkan antara peristiwa masa lalu dengan masa kini secara sederhana. Konsep waktu yang dianggap abstrak bagi siswa sekolah dasar dapat dimudahkan dengan adanya pembelajaran sejarah secara tematik.

\section{SIMPULAN DAN REKOMENDASI}

Berdasarkan uraian pada hasil dan pembahasan dapat disimpulkan bahwa dalam buku tematik terpadu di sekolah dasar telah memuat konten sejarah. Tema yang berisi materi sejarah telah disajikan dalam beberapa tema. Tema tersebut diantaranya tema 5 " pahlawanku" di kelas IV yang terdiri dari tiga subtema (perjuangan para pahlawan, pahlawan kebanggaanku, sikap kepahlawanan), tema 7 "peristiwa dalam kehidupan" di kelas V yang terdiri dari subtema (peristiwa kebangsaan masa penjajahan, peristiwa kebangsaan seputar proklamasi kemerdekaan, peristiwa mengisi kemerdekaan), dan tema 3 "tokoh dan penemuan di kelas VI yang dibagi menjadi subtema (penemu yang mengubah dunia, penemu dan manfaatnya serta ayo menjadi penemu. Nilai-nilai yang dapat ditemukan antara lain: nilai edukatif, nilai instruktif, nilai rekreatif dan nilai inspiratif. Nilai karakter yang ditemukan antara lain nilai kepahlawanan, perjuangan, kerjasama dan nasionalisme.

Berdasarkan kesimpulan di atas terdapat beberapa rekomendasi yang diberikan kepada guru dalam mengimplementasikan pembelajaran sejarah secara tematik di sekolah dasar. Pertama, pembelajaran sejarah hendaknya mengedepankan penanaman nilai karakter, tidak hanya mengedepankan hafalan.
Kedua, Buku tematik telah menyajikan konten sejarah dengan sangat baik maka dari itu guru harus mampu memfasilitasi siswa agar pembelajaran sejarah dapat bermakna bagi kehidupan siswa. Ketiga, Stigma negatif bahwa pembelajaran sejarah membosankan, hendaknya dirubah melalui perbaikan dalam metode dan media pembelajaran yang digunakan. Keempat, Setelah mengetahui nilainilai edukasi yang terdapat dalam muatan materi sejarah hendaknya siswa lebih semangat lagi dalam belajar sejarah.

\section{DAFTAR PUSTAKA}

Akbar, A. (2014). Cultural Resource Management for a Majapahit Kingdom Site in Trowulan, East Java, Indonesia. Conservation and Management of Archaeological Sites, 16(4), 297-307. https://doi.org/10.1179/1350503315Z. 00000000099

Anggari, A. S., Afriki, Wulan, D. R., Puspitawati, N., Khasanah, L. M., \& Hendriyeti, S. (2017). Pahlawanku: Buku Tematik Terpadu Kurikulum 2013 (4th ed.). Jakarta: Pusat Kurikulum dan Perbukuan, Balitbang, Kemendikbud.

Anggari, A. St., Afriki, Wulan, D. R., Puspitawati, N., Khasanah, L. M., \& Hendriyeti, S. (2018). Tokoh dan Penemuan: Buku Tematik Terpadu Kurikulum 2013 (2nd ed.). Jakarta: Pusat Kurikulum dan Perbukuan, Balitbang, Kemendikbud.

Anto, A., \& Nuraini, F. (2020). Social Accounting and Tax Accountability: An Interpretive Study of the Majapahit Empire. Jurnal Dinamika Akuntansi, 12(2), $140-151$. https://doi.org/10.15294/jda.v12i2.256 72

Clifton, W., \& Damon, A. (2020). The three-dimensional printing renaissance of individualized anatomical modeling: Are we repeating history? Clinical Anatomy, 33(3), 428-430. 
https://doi.org/10.1002/ca.23545.

Furinghetti, F. (2020). Rethinking history and epistemology in mathematics education. International Journal of Mathematical Education in Science and Technology, 51(6), 967-994. https://doi.org/10.1080/0020739X.201 9.1565454 .

HDPGSDI. (2020). Profil dan Capaian Pembelajaran Lulusan (CPL) Sarjana, Magister, dan Doktor PGSD/Pendidikan Dasar. Makasar.

Hein, C., \& van Dooren, E. (2020). Teaching history for design at TU Delft: exploring types of student learning and perceived relevance of history for the architecture profession. International Journal of Technology and Design Education, 30(5), 849-865. https://doi.org/10.1007/s10798-01909533-5.

Hernawan, A. H., Resmini, N., \& Andayani. (2011). Pembelajaran Terpadu di SD. Jakarta: Universitas Terbuka.

Jacobs, J. M., \& Templin, T. (2020). The Man Behind the Teaching Personal and Social Responsibility Model: A Life History of Don Hellison. Journal of Teaching in Physical Education, 39(3), 289-299.

https://doi.org/10.1123/jtpe.20190220.

Jankvist, U. T., Clark, K. M., \& Mosvold, R. (2020). Developing mathematical knowledge for teaching teachers: potentials of history of mathematics in teacher educator training. Journal of Mathematics Teacher Education, 23(3), 311-332. https://doi.org/10.1007/s10857-01809424-X.

Kartodirdjo, S. (1992). Pendekatan ilmu sosial dalam metodologi sejarah. Jakarta: PT Gramedia Pustaka Utama.

Komatsu, H., \& Rappleye, J. (2020). Reimagining Modern Education: Contributions from Modern Japanese
Philosophy and Practice? ECNU Review of Education, 3(1), 20-45. https://doi.org/10.1177/209653112090 5197.

Lim, K. Y. T., \& Lim, R. (2020). Semiotics, memory and augmented reality: History education with learner-generated augmentation. British Journal of Educational Technology, 51(3), 673-691. https://doi.org/10.1111/bjet.12904.

Madjid, M. D., \& Wahyudhi, J. (2014). Ilmu Sejarah: Sebuah Pengantar. Jakarta: Kencana.

Maryanto, Fransiska, Kusumawati, H., Puspa, D., \& Subekti, A. (2017). Peristiwa dalam Kehidupan: Buku Tematik Terpadu Kurikulum 2013 (2nd ed.). Jakarta: Pusat Kurikulum dan Perbukuan, Balitbang, Kemendikbud.

Permatasari, E. A. (2014). Implementasi Pendekatan Saintifik Dalam Kurikulum 2013 Pada Pembelajaran Sejarah. Indonesian Journal of History Education, 3(1), 11-16. Retrieved from

https://journal.unnes.ac.id/sju/index.ph p/ijhe/article/view/3884.

Rachmah, H. (2014). Pengembangan Profesi Pendidikan IPS. Bandung: Alfabeta.

Rexhepi, J. (2020). Kosova And The Social And Cultural Life During The Years 1945-1990. Anglisticum Journal, 9(4), 32-37.

https://doi.org/10.0001/ijllis.v9i4.2075. g2484.

Stein, S. (2020). A colonial history of the higher education present: rethinking land-grant institutions through processes of accumulation and relations of conquest. Critical Studies in Education, 61(2), 212-228. https://doi.org/10.1080/17508487.2017 .1409646.

Suryanegara, A. M. (2014). Api Sejarah 1. Bandung: Cv. Tria Pratama.

Takayama, K. (2020). Engaging with the 


\section{PRIMARY: JURNAL PENDIDIKAN GURU SEKOLAH DASAR \\ VOLUME 10 NOMOR 3 JUNI 2021 \\ ISSN : 2303-1514 | E-ISSN : 2598-5949 \\ DOI : http://dx.doi.org/10.33578/jpfkip.v10i3.8123 \\ https://primary.ejournal.unri.ac.id/index.php/JPFKIP}

More-Than-Human and Decolonial Turns in the Land of Shinto Cosmologies: "Negative" Comparative Education in Practice. ECNU Review of Education, 3(1), 46-65. https://doi.org/10.1177/209653112090 6298.

Widodo, A. (2020). Nilai Budaya Ritual Perang Topat Sebagai Sumber Pembelajaran IPS Berbasis Kearifan Lokal di Sekolah Dasar. Gulawentah:Jurnal Studi Sosial, 5(1), 1-16.

https://doi.org/10.25273/gulawentah.v 5 i1.6359.

Widodo, A., Akbar, S., \& Sujito, S. (2017). Analisis nilai-nilai falsafah Jawa dalam buku pitutur luhur budaya Jawa karya Gunawan Sumodiningrat sebagai sumber belajar pada pembelajaran IPS. Jurnal Penelitian Dan Pendidikan IPS (JPPI), 11(2), 152-179. Retrieved from http://ejournal.unikama.ac.id/index.ph p/JPPI/article/download/1887/1489/.

Yarmatov, R. B., \& Qizi, A. M. X. (2020). Preparation Of Future History Teachers For Pedagogical Practice In Pedagogical Institutions Of Higher Education. Journal of Critical Reviews, $\quad 7(15), \quad 2463-2470$. https://doi.org/10.31838/jcr.07.14.199. 